\title{
THE EFFICACY OF A POSTERIOR SUB-TENON'S CAPSULE TRIAMCINOLONE INJECTION IN PATIENTS WITH NON-INFECTIOUS INTERMEDIATE UVEITIS AND POSTERIOR UVEITIS
}

Gordana Andjelic ${ }^{1}$, Svetlana Jovanovic ${ }^{2}$, Snezana Pesic ${ }^{3}$, Milos Mitrasevic ${ }^{4}$, Jasmina Stojanovic ${ }^{5}$, Filip Radotic ${ }^{3}$, Dusan Todorovic ${ }^{3}$, Nenad Petrovic ${ }^{2}$ ${ }^{1}$ Health Centre "Sveti Đorđe", Topola, Serbia

${ }^{2}$ Clinic of ophthalmology, Clinical Centre Kragujevac, Kragujevac, Serbia

${ }^{3}$ Faculty of Medical Sciences, University of Kragujevac, Kragujevac, Serbia

${ }^{4}$ Department for Hospital Healthcare, Clinical Centre Kragujevac, Kragujevac, Serbia,

${ }^{5}$ Clinic of Otorhinolaryngology, Clinical Centre Kragujevac, Kragujevac, Serbia

\section{EFIKASNOST ZADNJE SUBTENONSIE INJEICIJE TRIAMCINOLONA IKOD PACIJENATA SA INTERMEDIJALNIM I ZADNJIM UVEITISOM NEINFEKTIVNE ETIOLOGIJE}

Gordana Anđelić ${ }^{\text {, Svetlana Jovanović }}$, Snežana Pešić ${ }^{3}$, Miloš Mitraševićc ${ }^{4}$, Jasmina Stojanović ${ }^{5}$, Filip Radotić $^{3}$, Dušan Todorović ${ }^{3}$, Nenad Petrović ${ }^{2}$ ${ }^{1}$ Dom Zdravlja “Sveti Đorđe”, Topola, Srbija

${ }^{2}$ Klinika za oftalmologiju, Klinički centar Kragujevac, Kragujevac, Srbija

Fakultet medicinskih nauka, Univerzitet u Kragujevcu, Kragujevac, Srbija

${ }^{4}$ Odsek za zdravstvenu zaštitu, Klinički centar Kragujevac, Kragujevac, Srbija

Received / Primljen: 17.03.2016.

\begin{abstract}
To investigate the efficacy of a posterior sub-Tenon's capsule triamcinolone injection for treating eyes with non-infectious posterior and intermediate uveitis.

A total of 31 eyes from 20 patients with non-infectious posterior uveitis and 18 eyes from 10 patients with non-infectious intermediate uveitis that inadequately responded to treatment with systemic corticosteroids and second-line immunosuppressive agents were enrolled in the study. All patients received a posterior sub-Tenon's injection of $20 \mathrm{mg} / \mathrm{ml}$ triamcinolone. The parameters we examined included the following: best corrected visual acuity, central foveal thickness, fluorescein angiography score and intraocular pressure.

The mean best corrected visual acuity was significantly improved from the control visit, $0.15 \pm 0.30 \log M A R$ (Snellen equivalent 0.7 ), compared to the baseline measurements, $0.60 \pm 0.30 \log M A R$ (Snellen equivalent 0.25; $P<0.05$ ). The mean central foveal thickness (CFT) and the mean score for fluorescein angiography (FA) were significantly decreased from the baseline (CFT: $320 \pm 34 \mu m$; FA mean score: $5.9 \pm 1.9$ ) compared to the twelve-week control visit (CFT: $235 \pm 30 \mu \mathrm{m}$; FA mean score: $1.2 \pm 1.1 ; P<0.001$ ). Five eyes had intraocular pressure spikes that required a topical anti-glaucomatous treatment.
\end{abstract}

A posterior sub-Tenon's injection of triamcinolone can significantly improve visual acuity and decrease macular oedema in patients with non-infectious posterior and intermediate uveitis. Complications were minimal, and there were no eyes that required surgical treatment for elevated intraocular pressure. The results suggest that the posterior sub-Tenon's injection of triamcinolone is an important form of therapy for non-infectious posterior and intermediate uveitis.

Keywords: Intermediate uveitis, posterior uveitis, triamcinolone, fluorescein angiography

\section{SAŽETAK}

Isptitivanje efikasnosti zadnje subtenonske injekcije triamcinolona (PSTI) u terapiji očiju sa intermedijalnim $i$ zadnjim uveitisom neinfektivne etiologije.

u studiju je uključeno ukupno 31 oko od 20 pacijenata sa zadnjim uveitisom $i 18$ očiju od 10 pacijenata sa intermedijalnim uveitisom neinfektivne etiologije koji neadekvatno reaguju na kombinaciju terapije sistemskih kortikosteroida $i$ druge linije imunosupresivnih medikamenata. Svi pacijenti su primili zadnju subtenonsku injekciju $20 \mathrm{mg} / \mathrm{ml}$ triamcinolona. Parametri koje smo pratili su: najbolje korigovana vidna oštrina, centralna fovealna debljina, skor fluoresceinske angiofrafije i intraokularni pritisak.

Sredna vrednost najbolje korigovane vidne oštrine je statistički značajno poboljšana na kontrolnoj poseti $0.15 \pm 0.30 \log M A R$ (Snellen ekvivalent 0.7) u odnosu

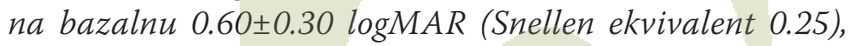
$P<0.05$. Srednja centralna fovealna debljina (CFT) $i$ srednji skor fluoresceinske angiografije (FA) su bili statistički značajno smanjeni na kontroli u 12 nedelji (CFT: 235 \pm 30 um; FA srednji skor: 1.2 1.1) u odnosu na bazalni (CFT:

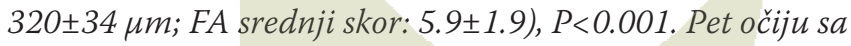
skokom intraokularnog pritiska je zahtevalo lokanu antiglaukomatoznu terapiju.

Zadnja subtenonska injekcija triamcinolona može statistički značajno poboljšati vidnu oštrinu i smanjiti edem makule kod pacijenata sa zadnjim i intermedijalnim uveitisom neinfektivne etiologije. Komplikacije su bile minimalne i nije bilo očiju koje su zahtevale hirušku terapiju povišenog intraokularnog pritiska. Rezultati sugerišu da zadnja subtenonska injekcija triamcinolona je važan oblik u terapiji zadnjih i intermedijalnih uveitisa neinfektivne etiologije.

Ključne reči: intermedijalni uveitis, zadnji uveitis, triamcinolon, fluoresceinska angiografija 


\section{INTRODUCTION}

Non-infectious posterior and intermediate uveitis comprises a group of diseases associated with inflammation of the eye that can lead to vision loss. A number of patients with uveitis have macular oedema. Macular oedema is treated with systemic medications, but the treatment does not always prevent vision loss. In some eyes, macular oedema persists even after the inflammation is controlled and requires an additional treatment to improve vision. This approach is currently completed with and additional systemic corticosteroid and/or ocular corticosteroid injections (1).

Triamcinolone is a long-acting synthetic corticosteroid that is effective against a certain level of inflammation and uveitic macular oedema when it is administered by an intravitreal or sub-Tenon`s capsule injection as a derivative acetonide (2). Intravitreal injections carry the risk of glaucoma $(3,4,5)$, cataracts $(6)$ and severe vision-threatening ocular complications in patients with posterior and intermediate uveitis, such as intraocular haemorrhage, retinal detachment and endophthalmitis $(7,8)$.

A periocular posterior sub-Tenon`s capsule injection of corticosteroids is an alternative route through which a certain amount of a drug can be delivered to the posterior segment of the eye via transscleral absorption. An image from a previous study showed that the fluid injected in the sub-Tenon space diffuses into the surrounding orbital tissues (9). The rationale behind the usage of this technique lies in its ability to inhibit the arachidonic acid pathway, regulate the production of cytokines, and reduce the breakdown of the blood-retinal barrier (10). Therefore, we used the posterior route to administer steroids. The bestfit line, according to the literature data, suggests that the effect of a posterior sub-Tenon`s triamcinolone injection in a $20-\mathrm{mg}$ dose lasts approximately 1 year (11).

The purpose of this study was to evaluate the results of a posterior sub-Tenon`s triamcinolone injection (PSTI) in the treatment of eyes with non-infectious posterior and intermediate uveitis.

\section{SUBJECTS AND METHODS}

This was a prospective interventional study that lasted from January 2013 to June 2014 and included 31 eyes from 20 patients with non-infectious posterior uveitis and 18 eyes of 10 patients with non-infectious intermediate uveitis that inadequately responded to treatment with a systemic corticosteroid and second-line immunosuppressive agents. Laboratory tests were performed to rule out infectious uveitis if the subject did not already have an infectious type of uveitis at the time of the uveitis diagnosis.

Examination was conducted at baseline, 1 week after treatment, 4 weeks and 12 weeks after treatment.

The following examinations were required for all patients who were included in the study: (1) best corrected visual acuity (BCVA), determined with illuminated log-
Table 1. Modified Fluorescein Angiographic Grading System for Macular Oedema

\begin{tabular}{|c|l|}
\hline Grade & Characteristics \\
\hline 0 & No perifoveal hyperfluorescence \\
\hline 1 & $\begin{array}{l}\text { Faint perifoveal hyperfluorescence; specific localization of } \\
\text { hyperfluorescence was too difficult because of very minimal } \\
\text { leakage }\end{array}$ \\
\hline 2 & $\begin{array}{l}\text { Evident perifoveal hyperfluorescence in an area centred on } \\
\text { the fovea of less than } 1 \text { optic disc diameter }\end{array}$ \\
\hline 3 & $\begin{array}{l}\text { Evident perifoveal hyperfluorescence in an area centred on } \\
\text { the fovea between } 1 \text { and } 1.5 \text { optic disc diameter(s) in size }\end{array}$ \\
\hline
\end{tabular}

MAR charts (logarithm of minimum angle of resolution), (2) IOP of both eyes measured with Goldmann applanation tonometry, (3) ophthalmic examination including dilated ophthalmoscopy and a slit-lamp examination (for lens assessment), (4) fluorescein angiography (FA) and (5) optical coherence tomography (OCT).

The clinical evaluation of macular oedema was performed during a stereoscopic slit-lamp fundus examination using both non-contact (+90 diopters) and Goldmann contact lens and colour photographs of fundus. The tests for evaluating macular oedema were grouped into three categories, according to whether they analysed the underlying pathogenesis, the effect of macular oedema on the retina, or its impact on visual function: a) the test for assessing macular function was the control of visual acuity, b) the test for detecting disturbances in the blood-retinal barrier was the fluorescein angiogram of the fundus, and c) the test for detecting retinal tissue thickness was optical coherence tomography.

BCVA was measured using logarithmic visual acuity charts (logMAR) and recorded as the number of standard letters that were read correctly. These measurements were taken in all subjects at baseline (score upon entering the study), 1 week after treatment and 12 weeks after treatment.

Optical coherence tomography (OCT) detected and measured small changes in the macular thickness and quantitatively estimated them. At OCT, we measured central foveal thickness in micrometres. The central foveal thickness represents the thickness at the point of intersection of 6 radial scans. OCT was performed with a Stratus OCT device (Stratus 3000, software version 4.0.1 Carl Zeiss Meditec, Inc., Dublin, California, USA).

For fluorescein angiography, we recorded the following information: Retinal oedema was measured in three concentric areas of the centre foveae, with a width of 500 microns each. We graded these variables as none (0), mild (1), moderate (2), and severe (3). Fluorescein angiograms were graded according to a modified grading system (Table 1), which included a combination of the criteria reported by Yannuzzi and the proposed grading system of the Angiography Scoring for Uveitis Working Group $(12,13)$. Macular oedema was assessed through images obtained at least 5 minutes after intravenous injection of $5 \mathrm{~mL} 20 \%$ sodium fluorescein. In this study, only the subjects in which there was obvious leakage in the centre (grades 2,3) were 
classified and analysed as having macular oedema. We did not have any patients with evident perifoveal hyperfluorescence in an area centred on the fovea of more than 1.5 optic disc diameters (grade 4). We defined clinical improvement as an improvement in the total score of these criteria after 12 weeks compared to our baseline clinical findings.

In the evaluation of macular oedema with optical coherence tomography, we recorded information on retinal thickening in the macula at baseline and 12 weeks after the application of a posterior Sub-Tenon`s injection of triamcinolone.

The IOP was measured by Goldmann applanation tonometer immediately before and one day after a posterior Sub-Tenon`s injection of triamcinolone. Repeat measurements of IOP were collected with Goldmann applanation tonometry 1 week after PSTI and then at intervals of 1 to 4 weeks for at least 3 months, according to the patients' clinical needs of the patients.

At follow-up appointments, if the IOP was $>25 \mathrm{~mm}$ $\mathrm{Hg}$ but $<30 \mathrm{mmHg}$, one topical anti-glaucoma medication was started. If the IOP was $>30 \mathrm{~mm} \mathrm{Hg}$ but $<35 \mathrm{mmHg}$ or $>35 \mathrm{mmHg}$ but $<40 \mathrm{mmHg}$, 2 or 3 topical anti-glaucoma medications were started, respectively. If the IOP was $>40$ $\mathrm{mmHg}, 3$ topical anti-glaucoma medications and oral acetazolamide were administered. Lens status was noted in a slitlamp examination, and lens opacities were graded (as present or absent and whether they were visually significant) by LOCS III (Lens Opacities Classification System III) (14). We applied this scale in short-term clinical trials for the drug triamcinolone, which has cataractogenic potential.

\section{Data Analysis}

Visual acuity was converted to the Logarithm of Minimum Angle Visual Acuity a (LogMAR) for the purpose of statistical analysis. Changes in BCVA and CFT over time were analysed with a paired sample $t$-test. The statistical analysis was performed using SPSS (version 15.0, SPSS Inc., Chicago, IL, USA).

\section{Ethical approval}

Ethical approval was obtained from: Ministry of Health, Republic of Serbia No: 500-01-00035, Commission for Health Technology Assessment.

\section{TREATMENT PROTOCOL}

\section{Sub/Tenon`s Injection}

The standardized procedure for the preparation of the ocular surface prior to the injection of triamcinolone is as follows: (1) administration of topical ofloxacin (Uniflox, Unimed pharma) on the day of injection (use of 3 drops over a period of at least 15 minutes); (2) administration of topical $0.5 \%$ tetracaine anaesthetic drops on the con-

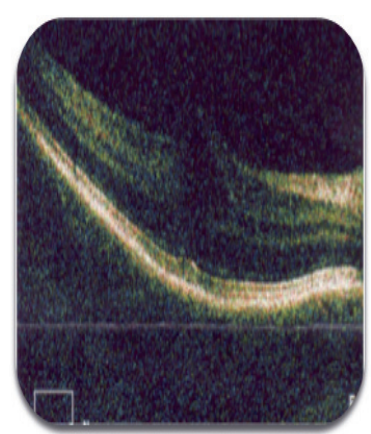

a) OD before PSTI application procedure

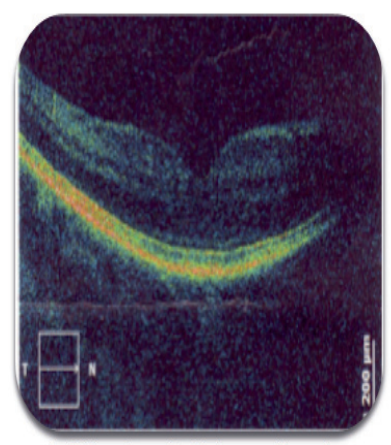

c) OD after PSTI application procedure

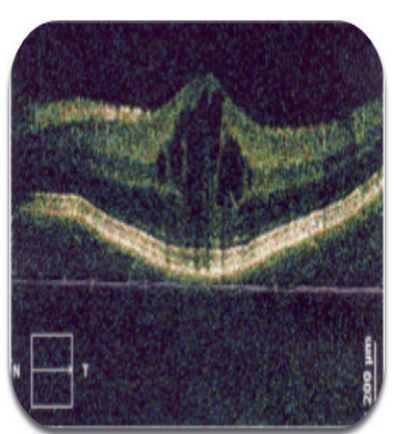

b) OS before PSTI application procedure

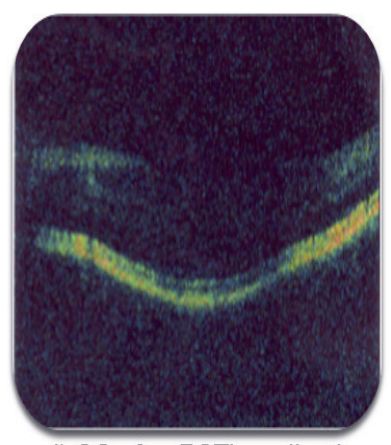

d) OS after PSTI application procedure

Figure 1. Macular oedema of the right and left eye of the same patient before $(\mathrm{a}, \mathrm{b})$ and after the PSTI procedure $(\mathrm{c}, \mathrm{d})$

junctiva inferonasally to the limbus for 3 minutes before injection; (3) application of two to three drops of $5 \%$ povidone-iodine in the lower fornix that were allowed to dry for 30-60 seconds; and (4) usage of a sterile eyelid speculum to separate the eyelids.

The study drug was formulated and manufactured as a sterile, triamcinolone acetonide injectable suspension (20 mg per $1 \mathrm{ml}$, brand name Kenalog 40, Krka, Novo mesto, Slovenia). The patient was instructed to look in the contralateral direction of the eye that was to receive the injection. The upper eyelid was lifted, and the inferonasal conjunctival fornix was penetrated with the needle bevel down. After the tip of the needle entered the fornix, the needle was rotated by 180 degrees with the bevel up. The needle advanced along the sclera posteriorly and slowly with a side-to-side sweeping motion until the hub of the needle was reached. Then, an injection of $1 \mathrm{ml} 20 \mathrm{mg} / \mathrm{ml}$ triamcinolone was given (Figure 1). The eyelid speculum was removed. The subjects were instructed to use topical ofloxacin 4 times a day for 3 days following the injection.

\section{RESULTS}

Forty-nine eyes from 30 patients were included in the study, including 20 patients with posterior uveitis and 10 patients with intermediate uveitis. 
Table 2. Details and follow-up for the uveitis group of patients treated with a posterior sub-Tenon`s injection triamcinolone

\begin{tabular}{|l|l|}
\hline Uveitis group, $\mathbf{N}=\mathbf{3 0}$, eyes $=49$ & \\
\hline mean follow-up time & $14.7 \pm 8.6$ months \\
\hline mean ages & $39.5 \pm 24.5$ years \\
\hline duration of uveitis & $21 \pm 7$ months \\
\hline Unilateral / bilateral & $18(40 \%) / 12(60 \%)$ \\
\hline posterior uveitis / intermediate uveitis & $\mathrm{n}=20 / 10$ eyes $=31 / 18$ \\
\hline
\end{tabular}

Table 2 summarizes the ophthalmic data and other clinical data collected from the participating subjects. The patients had a mean follow-up time of $14.7 \pm 8.6$ months (range, 3-36) after PSTI. The mean age of the patients was $39.5 \pm 24.5$ years (range, 28 - 77) in the PSTI group. The average duration of uveitis was $21 \pm 7$ months (range, 5 - 34). Eighteen (40\%) patients had a bilateral version of the disease.

Table 3. Evaluation of visual function before and after a posterior sub-Tenon`s injection triamcinolone

\begin{tabular}{|l|l|l|l|}
\hline $\begin{array}{l}\text { BCVA } \\
\text { N=49 eyes }\end{array}$ & $\begin{array}{l}\text { Before treatment } \\
\text { (baseline score) }\end{array}$ & 1 week after the treatment & 12 weeks after treatment \\
\hline Mean BCVA scores logMAR & $0.60 \pm 0.30$ & $0.17 \pm 0.30$ & $0.15 \pm 0.30$ \\
\hline Mean BCVA Snellen equivalent) & $0.25(0.35-0.22)$. & $0.67(0.63-0.32)$ & $0.7(0.78-0.32)$ \\
\hline paired t - test & & $\mathrm{P}<0.05$ & $\mathrm{P}<0.05$ \\
\hline
\end{tabular}

Table 4. Fluorescein angiography analysis of CME

\begin{tabular}{|l|l|l|}
\hline & baseline & 12 weeks \\
\hline Mean FA score \pm SD & $5.2 \pm 1.9$ & $1.2 \pm 1.1$ \\
\hline paired t-test & & $\mathrm{P}<0.001$ \\
\hline
\end{tabular}

Table 5. Optical coherence tomography analysis of CME

\begin{tabular}{|l|l|l|l|}
\hline $\mathbf{n}=\mathbf{4 9}$ eyes & baseline & $\mathbf{1 2}$ weeks & $\begin{array}{l}\text { average } \\
\text { improvement }\end{array}$ \\
\hline $\begin{array}{l}\text { Mean central foveal } \\
\text { thickness }( \pm \text { SD) }\end{array}$ & $320 \pm 34 \mu \mathrm{m}$ & $235 \pm 30 \mu \mathrm{m}$ & $85 \mu \mathrm{m}$ \\
\hline $\mathrm{P}$ & & & $<0.001$ \\
\hline
\end{tabular}

Table 6. Intraocular pressure before treatment,

12 weeks and 18 weeks after PSTI

\begin{tabular}{|l|l|l|l|}
\hline $\mathbf{n}=\mathbf{4 9}$ eyes & baseline & $\mathbf{1 2}$ weeks & $\mathbf{1 8}$ weeks \\
\hline mean $\mathrm{IOP} \pm \mathrm{SD}$ & $20 \pm 1.4 \mathrm{mmHg}$ & $22 \pm 2.1 \mathrm{mmHg}$ & $21 \pm 2.1 \mathrm{mmHg}$ \\
\hline $\mathrm{P}$ & & & $>0.05$ \\
\hline
\end{tabular}

Table 7. Intraocular pressure for the study subjects

\begin{tabular}{|l|l|l|}
\hline IOP & $\mathbf{n}(\%)$ & Anti-glaucoma medication \\
\hline mild & $4(8 \%)$ & $/$ \\
\hline rise of $>25 \mathrm{mmHg}$ & $3(6 \%)$ & 1 topical anti-glaucoma medication \\
\hline rise of $>30 \mathrm{mmHg}$ & $1(2 \%)$ & 2 topical anti-glaucoma medications \\
\hline rise of $>35 \mathrm{mmHg}$ & $/$ & $/$ \\
\hline rise of $>40 \mathrm{mmHg}$ & $1(2 \%)$ & $\begin{array}{l}\text { 3 topical anti-glaucoma medications } \\
\text { and oral acetazolamide }\end{array}$ \\
\hline$\Sigma$ & $9(18 \%)$ & \\
\hline
\end{tabular}

Cystoid macular oedema was defined throughusing three categories of tests: visual function, fluorescein angiography and OCT.

Tests for evaluating visual function: Best Corrected Visual Acuity was measured using the Logarithm of Minimum Angle Visual Acuity. Before treatment, the mean BCVA score was $0.60 \pm 0.30 \log$ MAR (Snellen equivalent 0.25 mean, range, $0.35-0.22$ ). After the first week of treatment, the corresponding value was $0.17 \pm 0.30 \log$ MAR (Snellen equivalent 0.67 mean, range 0.63 - 0.32). The twelve-week score was $0.15 \pm 0.30 \operatorname{logMAR}$, (Snellen equivalent 0.7 mean, range 0.78 - 0.32) (Table 3). When the baseline scores were compared to thosethese scores with an unpaired t-test, there was a statistically significant difference between the BCVA before treatment, 1 week after treatment and 12 weeks after treatment $(\mathrm{P}<0.05)$.

Fluorescein angiography analysis: The mean baseline score before treatment was $5.2 \pm 1.9$ (mean, SD). Twelve weeks after treatment, the corresponding value was 1.2 \pm 1.1 (mean, SD) (Table 4.)

Optical coherence tomography $(\mathrm{OCT})$ : OCT was analysed in 49 eyes of 30 patients. The mean central foveal thickness $( \pm$ SD) decreased sharply by $85 \mu \mathrm{m}$ from $320 \pm 34$ $\mu \mathrm{m}$ at baseline to $235 \pm 30 \mu \mathrm{m}$ at 12 weeks. In the treatment group, a significant reduction in the mean macular thickness $(\mathrm{P}<0.001)$ was detected 12 weeks after the injection (Table 5).

Table 8. Lens status of the study subjects

\begin{tabular}{|l|l|l|l|l|l|}
\hline lens status & $\begin{array}{l}\text { cataracta complicata } \\
\text { uveitica }\end{array}$ & $\begin{array}{l}\text { cataracta complicata } \\
\text { medicamentosa }\end{array}$ & cataracta senilis & suma & $\begin{array}{l}\text { phacoemulsification } \\
\text { with IOL } \\
\text { implantation }\end{array}$ \\
\hline $\mathrm{N}(\%)$ & $4(8 \%)$ & $1(2 \%)$ & $2(4 \%)$ & $\mathrm{N}=7(14 \%)$ & $4(8 \%)$ \\
\hline
\end{tabular}


Intraocular pressure: The mean IOP increased from $20 \mathrm{mmHg}$ at baseline (range $18-22 \mathrm{mmHg}$ ) to a mean maximal value of 32 (range $22-40 \mathrm{mmHg}$ ) and then decreased to $21 \mathrm{mmHg}$ (range $17-23 \mathrm{mmHg}$ ) at the end of the study (Table 6).

Four eyes (8\%) out of 49 eyes in the PSTI group developed mild elevation of intraocular pressure (up to 25 $\mathrm{mmHg}$ ). We managed to control them without topical anti-glaucoma agents, which corresponded to final IOP levels of 15 and $16 \mathrm{mmHg}$.

During the study period, 3 eyes (6\%) had an IOP rise of $>25 \mathrm{mmHg}$, whereas 1 eye $(2 \%)$ had an IOP rise of $>30$ $\mathrm{mmHg}$. One eye (2\%) had a maximal IOP > $40 \mathrm{mmHg}$. After the injection, the mean time for detecting an IOP rise of $>5 \mathrm{mmHg}$ was 4 weeks. Five eyes $(10 \%)$ required some form of anti-glaucoma medication during the follow-up. The mean duration of the anti-glaucoma treatment was 17 weeks (min 4, max 20) (Table 7).

Lens Changes: Seven eyes (14\%) had cataracts (mean age, 44 years (range 28-65), and the remaining patients had a clear lens (mean age, 42 years (range 27-64). These patients had a mean follow-up time of 15 months (range $3-26)$. Four eyes (8\%) had complicated cataracts due to the effects of chronic uveitis, 1 eye $(2 \%)$ had a cataract as an effect of corticosteroids and 2 eyes $(4 \%)$ had senile cataracts. Four eyes (8\%) were treated with phacoemulsification and lens implantation (Table 8).

\section{DISCUSSION}

This study investigated the use of a posterior sub-Tenon's capsule triamcinolone injection for the treatment of macular oedema of non-infectious posterior and intermediate uveitis that could not be controlled with systemic medications (15). Macular oedema is the major cause of the loss of visual acuity in uveitis patients. In oedema, the blood-retinal barrier was damaged by an alteration in tight junctions between the retinal capillary endothelial cells and pigmented epithelial cells with consequent leakage in the retinal tissue.

This study demonstrated that 12 weeks after a sub-Tenon's triamcinolone injection, there was a statistical improvement in visual acuity and a significant reduction in retinal thickness. After 12 weeks, we also observed no statistically significant variations in IOP.

The main outcome measure of our study was the visual acuity score. Our results showed that early improvement after treatment (at 12 weeks) was significant. In the study, after a single posterior sub-Tenon`s capsule triamcinolone injection, we observed a statistically significant difference between the BCVA before treatment, 1 week after treatment and 12 weeks after treatment $(\mathrm{P}<0.01)$. Moreover, control of macular oedema was achieved for a mean duration of 12 weeks. Triamcinolone performed well as a long-acting corticosteroid and was effective against inflammation in uveitic macular oedema.
This study showed through measurement of the mean CFT by OCT and FA scores that a posterior sub-Tenon's capsule triamcinolone injection was significantly effective in the treatment of posterior uveitis and intermediate uveitis macular oedema throughout the follow-up period $(16,17)$.

In this study, although the mean IOP increased between the baseline measurements and the 1-month visit, it returned to the baseline level before the end of the study. A single sub-Tenon`s capsule injection of triamcinolone did not cause a statistically significant increase in IOP $(\mathrm{P}>0.05)$ in this study. Only 9 (18\%) out of 49 eyes had an IOP elevation that required medical treatment during the follow-up period. The rise in IOP reflectsed the pharmacokinetic properties of PSTI. However, a careful observation of IOP was necessary after administration of the posterior sub-Tenon`s capsule injection of triamcinolone.

A Sub-Tenon`s injection may be safer because there was no incidence of endophthalmitis.

During the 15-month follow-up period, 1 (2\%) out of 49 eyes developed posterior subcapsular opacities due to the corticosteroids. This effect of a posterior sub-Tenon`s capsule triamcinolone injection might be caused by the solubility of triamcinolone in the sub-Tenon's space, which promotes long-term steroid release (18). We think that 20 $\mathrm{mg} / \mathrm{ml}$ PSTI had a shorter action period, and as a result, it led to lower rates of cataract progression; ,this concentration also led to lower rates of secondary glaucoma.

A previous report $(19,20)$ found orbital fat prolapse and ptosis occurred in some patients after a superotemporal sub-Tenon's corticosteroid injection, but we did not have any similar complications with the inferonasal approach. After injection, nearly $50 \%$ of the solution resided in the orbital tissues anterior to the globe equator (11). This anterior diffusion of the solution in our patients did not contribute to the development of ptosis or fat prolapse after the posterior triamcinolone injection. This different approach for injection in our patients resulted in the absence of proptosis, and there was no need for multiple injections.

\section{CONCLUSION}

We have shown that a posterior sub-Tenon`s capsular triamcinolone injection is effective and safe for the treatment of intermediate and posterior uveitis. The assessment of the efficiency of macular oedema reduction was statistically significant at all levels of our evaluation by visual acuity, FA, and OCT. Additionally, the level of complications in the form of increased IOP and cataracts was not significant.

\section{REFERENCES}

1. Kempen JH, Altaweel MM. The multicenter uveitis steroid treatment trial: rationale, design, and baseline characteristics. Am J Ophthalmol. 2010;149:550-561 
2. Caskun E, Celemler P, Kimyon G, Oner V, KisacikB, rrbagci I, Mesut OA. Intravitreal Dexamethasone Implant for Treatment of Refractory Behçet Posterior Uveitis: One-year Follow-up Results. Ocular Immunology and inflammation 2015: 23(6)

3. Jonas JB, Degenring RF, Kreissig I, Akkoyun I, Kamppeter BA. Intraocular Pressure Elevation after Intravitreal Triamcinolone Acetonide Injection. Ophtalmology 2005;112,593-8.

4. Palmberg P. Risk factors for glaucoma progression: Where does intraocular pressure fit in? Arch Ophthalmol 2001;119:897-8.

5. Yamamoto Y, Komatsu T, Koura Y, Nishino K, Fukushima A, Ueno H. Intraocular pressure elevation after intravitreal or posterior sub-Tenon triamcinolone acetonide injection. Can J Ophthalmolo. 2008; 43(1):42-7 doi 10.3129/i07-186

6. Gilles MC, Simson JM, Billson FA, Luo W, Penfold P, Chua W, et al. Safety of an intravitreal injection of triamcinolone: results from a randomized clinical trial. Arch Ophtalmol 2004;122:336-40

7. Benz MS, Murray TG, Dubovy SR, Katz RS, Eifrig CW. Endophtalmitis caused by Mycobacterium chelonae abscessus after intravitreal injection of triamcinolone. Arch Ophtalmol 2003;121:271-3.

8. Nelson ML, Tennant MT, Sivalingam A, Regillo CD, Belmont JB, Martidis A.Infectious and presumed noninfectious endophthalmitis after intravitreal triamcinolone acetonide injection.Retina 2003;23(5):686-91

9. Negi, AK, Browning AC, Vernon AS, Single perioperative triamcinolone injection versus standard postoperative steroid drops after uneventful phacoemulsification surgery: Randomized controlled trial. J. Cataract Refract Surg. 2006; 32 (3): 468-74

10. McGhee CN. Pharmacokinetics of ophthalmic corticosteroids. Br J Ophthalmol 1992; 76:681-684

11. Helm CJ, Holland GN. The effect of posterior subtenon injection of triamcinolone acetonide in patients with intermediate uveitis. Am J Ophthalmol 1995;120:55-64.
12. Yannuzzi, L.A. A perspective on the treatment of aphakic cystoid macular edema. Surv Ophthalmol. 1984; 28: 540-553

13. Tugal-Tutkun, I., Herbort, C.P., Khairallah, M., and Angiography Scoring for Uveitis Working Group (ASUWOG). Scoring of dual fluorescein and ICG inflammatory angiographic signs for the grading of posterior segment inflammation (dual fluorescein and ICG angiographic scoring system for uveitis). Int Ophthalmol. 2010; 30: 539-552

14. Chylack LT Jr, Wolfe JK, Singer DM, Leske MC, Bullimore MA, Bailey IL, et al. The Lens Opacitates Classification Sistem III. The Longitudinal Study of Cataract Study Group. Arch Ophtalmol 1993;111:831-6.

15. Lafranco Dafflon M, Tran VT, Guex/Crosier Y, Herbot CP. Posterior sub-Tenon's steroid injections for the treatment of posterior ocular inflammation: indications, efficacy and side effects. Graefes Arch Clin Exp Ophthalmol 1999;237(4):289-95

16. Jovanović S, Vukosavljević M, Jovanović M, StanojevićPaović A. Oftalmološke manifestacije hronične sarkoidoze. Ser J Exp Clin Res 2008;9(1):27-30.

17. Zlatanović G, Jovanović S, Živković M, Zlatanović M, Srecković S, Radotić F. The efficacy of novel therapeutic modalities of isolated ocular vasculitis vs ocular vasculitis as a systemic disease. Med Glas Ljek komore Zenicko-Doboj kantona 2012;9(1):66-73

18. Pickrel A, Harris A, Ngo S, Amireskandari A, Stewart E, Siesky B. Delivery of Intraocular Triamcinolone Acetonide in the Treatment of Macular Edema Pharmaceutics 2012; 4(1), 230-42.

19. Dal Canto AJ, Downs-Kelly E, Pery JD. Ptosis and Orbital Fat Prolapse after Posterior Sub-Tenon's Capsule Triamcinolone Injection. Ophthalmology 2006; 112(6) 1092-97

20. Ferrante P, Ramsey A, Bunce C, Lightman S. Clinical trial to compare efficacy and side-effects of injection of posterior sub-Tenon triamcinolone versus orbital floor methylprednisolone in the management of posterior uveitis. Clin Experiment Ophthalmol. 2004;32(6):563-8 